\title{
REPETITIVE ELEMENTS AND THEIR OBJECTIVES IN ANCIENT AND CONTEM- PORARY MOSQUES
}

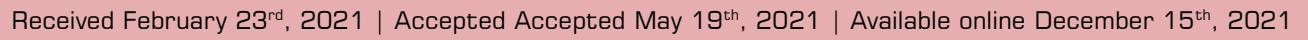
DOI http://dx. doi. org/10.18860/jia.v6i4.11718 |

\section{Aesha Adnan Gurjia}

Architectural Engineering Department, College of Engineering,

University of Mosul

Iraq

aeshaadnan93@gmail.com

\section{Ahmed Abdulwahid Dhannoon}

Architectural Engineering Department, College of Engineering,

University of Mosul,

Iraq

\begin{abstract}
Mosques are the most important buildings in Islamic architectures. They represent the place of worship for Muslims. Like other architectural buildings, they consist of components and repeated elements forming their general structures. However, some of these formal elements have changed due to the mosque development and the contemporary trends. Therefore, this research was conducted to discover the repetitive use of the elements and the differences between ancient and contemporary mosques by studying ten samples of mosques. It showed the difference between these two periods in terms of element repetition and utilization. Moreover, it tried to find the related objectives of repetitive use within these two periods. It concluded that some elements from the ancient period were used repetitively in the contemporary mosques. Based on the analysis findings, the design objective is achieved by the repetitive use in both periods. Furthermore, the repetitive use of the elements as structural objective takes second place in ancient mosques. Meanwhile, the environmental objective is second to achieve in contemporary mosques.
\end{abstract}

\section{KEYWORDS:}

Repetitive use; mosque architecture; mosque elements; mosque types; contemporary trends in mosque architecture.

\section{INTRODUCTION}

Repetition is the act of repeating or doing something again. A group of researchers, such as Chan [1], Al-Araji [2], Al-Khafaji [3], Thapa [4], Mohamed [5], and Taha [6], has studied repetition in art, motifs, and architecture. From these studies, we concluded the following definition of repetition in architecture:

Repetition is simply re-employing the same components, blocks, spaces, structural elements, and decorative elements to achieve certain aspects. For example, by repeating a specific element or a decorative unit in the components or facade of buildings, a sense of unity, continuity, and harmony can be achieved. This artistic effect mimics the experience of hearing a melody. Moreover, repetition can be employed to achieve a functional aspect, such as in the repetition of space modules. Structural objective can also be achieved by repeating columns and other structural elements.

Since the first mosque construction, repetition has been an essential feature in the architecture of ancient and contemporary mosques. The first manifestation of employing repetition is the Prophet's Mosque (also known as Al-Masjid an-Nabawi), consisting of a courtyard surrounded by walls from all sides. The qibla side is equipped with a sunshade supported by a series of columns. This general description characterizes the first mosque [7]. The prominent status of the Prophet's Mosque among Muslims influences the architecture of other mosques, in which the same concept of design is replicated. Two famous ancient mosques in Islam are The Great Mosque of Kairouan in Tunis and the Great Mosque in Cordoba [8]. In both mosques, repetition becomes a prominent facade in their structure and other components. In the Kairouan Mosque, the interior shows repetition through its arches and columns that extend along the arcades. In the prayer hall of Cordoba's Mosque, repetition is represented by columns and double arches [9]. These first models of mosques were called as Arabic-type mosques or hypostyle mosques.

A new style of mosques was built in Iran. Like the Arabic type, it features a central courtyard. However, the difference is in the using of two-story arcades (repeated columns and arches as structural building elements) surrounding the four sides to give a great sense of inclusion within the courtyard [10]. This style is well-known for using iwans (a rectangular hall or space, usually vaulted, walled on three sides). Mosques using this style are called as the Seljuk style or the Iranian type. Moreover, this style contributes to the emergence of large domes used to cover large prayer spaces and it is influenced by schools' buildings [7].

Another style of mosques appeared during the 
Ottoman Empire, and it was influenced by the design of the Hagia Sophia. This style is distinguished by the containment of a central area covered by a large dome surrounded by small and semi-domes and quarters of overlapping and repeated domes [7]. The dome became a basic unit in the structure of the mosque [8] Mosques of this style are called as the Ottoman style or the Turkish type.

Indian-style mosques also feature a central courtyard. They show a repetition of structural elements by using columns used in Hindu temples. Likewise, the repetitive use of the dome element is adopted. In addition, this style is characterized by the repetition of decorative treatments of engravings and floral motifs [8].

Finally, Chinese mosques and mosques in Southeast Asia, such as Malaysia and Indonesia, show a completely different style from the rest of the mosques in the Islamic world. This style is influenced by the home-grown building design using wooden structures. Prayer halls are square rather than rectangular; hierarchical roofs are repeated vertically and on several levels, and Chinese mosques are distinguished by their repetition of overlapping courtyards [11].

Contemporary mosques have set new trends, addressed by many studies, and lead to many classifications.

Jaleel classifies mosques into several trends. Some mosques are inspired by the ancient style but are built using modern materials and technology. Modern mosques that adopt hybridism are characterized by elements from early mosques (like domes and minarets), employed repetitively to allow visual continuity between the interior and the exterior. The style of hybrid mosques also matches the urban context of the site. Another type is non-traditional mosques with renewal tendency (unfamiliar mosques), and technological development has the most significant impact on their construction. Finally, nonphysical-form mosques do not have fixed or formal boundaries. Their flexibility distinguishes them since the number of worshipers determines their size and shape at the time of prayer [12].

Kamal conducted study on the relationship of a mosque with the urban site, the location's influence on the mosque, and the application of sustainability principles. The study used Dubai Creek Mosque as an example of a mosque linked to its urban surroundings. The mosque design forms a camel footprint in the desert. The form of a dome is used to reduce the thermal mass on the building envelope. The dome consists of multiple linear strips located at several levels of varying heights, which increases the roof's self-shading capability. Its design represents shapes formed in the desert sand, and the dome enhances the natural lighting inside the mosque and improves its natural ventilation [13].

Sojak dealt with a contemporary trend in mosque architecture, which focuses on environmental and sustainability aspects, modern building techniques, and their achievement from using repetition of decorations to perform an environmental function. Based on four samples (all located in Malaysia), he concluded that decorations in the facade layers acted as communication tools between the interior and the exterior. The researcher pointed out that ornaments reflect the environment, history, culture, and religion. Moreover, these decorations were produced using modern technologies. Thus, the importance of modern technology in the emergence of new types of decorations is highlighted. Furthermore, modern technology plays a major role in producing structural decorations, part of a building's structure, with specific effects. For example, digital decorations and media interfaces cannot be created using traditional ornament production methods [14].

Reviews on mosques' architecture in ancient and contemporary periods reveal that the principle of repetition is present in both eras. Additionally, the manifestation of various recurring elements (such as domes, minarets, arches, columns, and decorations) is used to achieve various objectives. Many studies highlight the repetition and their references to some repeated elements and objectives they have achieved. Nevertheless, none of the existing studies provides complete information on repeated elements regarding their quantity or continuity of use during the contemporary period.

Moreover, no comprehensive study provides a ratio of occurrence for each repeated element used during the two periods, nor did any research provide comprehensive information on the nature of the achieved objectives. Therefore, some questions are left unanswered, such as did the objectives remain constant? Did the original objectives of using repetition in mosque architecture during the ancient period change in the contemporary period?

Based on this knowledge gap, this research will apply a comparative statistical analysis approach between the two periods to determine the details of employing repetition in using elements. In addition, this research aims to identify the types and nature of the achieved objectives in each period. Finally, we also provide researchers and designers with design information about similarities and differences in employing this important design principle to help develop mosque designs in the future.

\section{METHODS}

This research includes a descriptive study of the main elements of mosques. The descriptive study shows which part is usually used in the repetition process and highlights all objectives for repeating these elements by studying the literature.

An analytical study is presented to investigate a group of mosques selected from two different periods (ancient and contemporary). Each mosque will be analyzed in detail using a statistical analysis approach, and a comparative approach will be used for the two periods. 
Conclusions will be presented regarding the nature of the repeating elements and their objectives to identify the similarities and differences in the usage of repetition between ancient and contemporary mosques.

\section{MAIN ELEMENTS OF MOSQUES}

Throughout history, many elements have been added to mosques with every development in mosque architecture. However, the following key elements have been used for centuries:

\section{- Prayer Hall}

It is one of the main elements in a mosque, which serves as a place for worshipers to gather and perform obligatory prayers. Worshipers stand in straight rows behind the imam and towards the Qibla direction to recite prayers [15].

- Mihrab

Placed in the direction of Qibla, the mihrab is a place for the imam in the mosque in front of worshipers [15]. Most mosques contain one mihrab, but some mosques have more than one.

- Minbar

It is a place for the imam delivers the Friday sermon, and it is usually located inside or near the mihrab [15].

- Courtyard

It is usually located at the center of the mosque. It is surrounded by arcades from the three sides and on the fourth side, where the prayer hall is located. The courtyard may serve as an additional area for prayers or an open space during religious occasions if the prayer hall is full. In addition, mosques have one or several courtyards if the mosque has multiple functions (i.e., educational, social, and religious) [15].

\section{- Dome}

It is used in mosques to cover the most significant possible space without using columns, blocking the view, and cutting the rows of worshipers. The dome is used in many forms, either as one large dome, the main one with half, or quarter parts of a dome. In addition, the dome may have different shapes, such as circular, oval, and onion. However, the Turkish mosques are most famous for their multiple domes [15]

- Minaret

It is the vertical element in mosques and it is used to call worshipers to pray. Symbolically, it raises the declaration of faith and acts as a visual focal point Minarets have many shapes, including squares, spirals, and pencils [15].

- Iwan

One of the famous elements in Persian mosques is a vaulted hall with one side opening towards a courtyard. The hall opening forms an arch that resembles a large portal [15].

\section{- Columns}

They have been used since the beginning of mosque architecture, particularly in the first mode of mosques represented by the Prophet's Mosque [8].

- Arches

As an element that has been widely used in all ancient mosques and some contemporary mosques, arches perform a constructive function. They can serve as columns, openings, and entrances, as well as decorative elements. Arches appear in several forms, including circular, pointed, or horseshoe shapes [16].

\section{- Ornaments}

Islamic buildings, including mosques, are distinguished by the ornaments that embellish their interiors and exteriors. In addition, some ornaments can be placed on domes and in mosques entrances. Ornaments are represented in several forms, including geometric, epigraphic, and botanical shapes [16].

These primary elements of mosque architecture can be used once or multiple times inside a mosque. In addition, other new elements appear in contemporary mosques, which often differ from the previously mentioned elements. These new elements are used for various reasons such as construction (e.g., precast elements) and environmental (e.g., air conditioning, lighting, and other elements that did not exist in ancient mosques).

\section{OBJECTIVES OF REPETITION}

Repetition can be done by utilizing some or all of the main elements of a mosque. Repetition is usually used to achieve objectives that may differ according to the type of element used.

The following most important objectives are achieved by repeating mosque elements, as discussed in other research papers.

1. Design

Repetition of elements can be used to achieve one of the following design goals.

- Unity and order: Unity is achieved through balance, harmony, and proportionality between elements [3].

- $\quad$ Rhythm and movement: These are achieved through the repetition of spaces or blocks consisting of units. Depending on the design, these units can be identical or differently positioned within small or large distances [3], [6].

- $\quad$ Element visibility and invisibility: These effects are achieved by emphasizing elements or reducing their importance by hiding them through the principle of perfect and imperfect repetition. Perfect repetition repeats the same item several times and identically. In contrast, imperfect repetition is similar to perfect repetition but incorporates simple changes in the repetitive architectural elements through details or the number of elements [3].

\section{Structural}

Specific structural elements in a mosque can be repeated, and the purpose of repetition is to create a 
structure that supports the building. In well-known mosques, load-bearing structural elements vary between the elements of columns, pointed arches, and horseshoe arches, which are intended to be repeated to form the building's structure[17].

\section{Environmental}

Repeating elements can serve one or many environmental objectives, such as introducing natural lighting and ventilation into a building, reducing energy consumption to reach the appropriate atmosphere, and providing shade from sunlight to reduce the sun glare entering the mosque. These objectives can be achieved by placing openings or facade treatments such as decorative elements [14].

\section{Symbolic/Semantic}

Symbolic and semantic purposes can be achieved through repetition. For example, local communities' identity and culture can be expressed by replacing Arab and Islamic motifs with local elements to create new and varied forms of decorations [14].

\section{MATERIALS AND METHODS}

The case study of this paper uses two sample groups. The first group represents the ancient period and the second group represents the contemporary period. The ancient period considers five classifications (as stated in the Introduction), and we will study one mosque for each type as follows:

1. Arabic type [10] [11]

2. Iranian type [11] or Seljuk style [10]

3. Turkish type [11] or Ottoman type [10]

4. Indian type [11]

5. Chinese and Southeast Asia types [11]

Examples from the contemporary period were selected from 27 mosques nominated in the third cycle of the Abdullatif Al-Fawzan Award for Mosque Architecture [18]. Thus, a total of 5 mosques were included in this study. Five types of mosques represent the contemporary period in mosque architecture, namely:

1. Mosques that combine ancient form with contemporary style and technique: This trend adopts the ancient form of elements in constructing the building's exterior shape but constructs it using contemporary techniques.

2. Mosques influenced by sustainability principles: In this trend, mosques are designed to provide a sustainable environment inside the mosque. This environment can be created by providing ventilation, natural lighting, and other important elements that make the mosque environment suitable while minimizing the energy sources.

3. Mosques influenced by modern technology and advanced building materials: These mosques use modern technology to implement their elements. The advance of technology helps recreating different forms of features and facilitates traditional elements using non-traditional materials.

4. Mosques influenced by the urban site's natural environment: the natural environment of the urban site influences these mosques. They emerge with new blocks in harmony with their location, different from the mosque's traditional shape, consisting of a dome and a minaret.

5. Non-conventional mosques: This trend includes mosques that unordinary in architecture and presents different design ideas with innovative mass and details.

\section{MOSQUES FROM THE ANCIENT PERIOD}

This research employed five mosque samples that represent each of the five types of ancient mosques. They were chosen due to the repetitive elements in their architecture. Moreover, the complete information including pictures and plans can be found in the literature.

\section{Arabic type (the hypostyle mosque): Ibn Tulun Mosque, Cairo, Egypt, 879 AD}

The mosque dates back to the ninth century. The most important characteristic of the mosque architecture is its arcades and corridors, creating a buffer area to reduce noise from the surroundings, as shown in Figure 1. Large pillars, each of which consists of four columns, support the arcades. The mosque has many entrances on its three sides, and many arched openings are used for lighting and structural purposes. In the middle of the courtyard, a dome is structured on pillars, and underneath it provides a fountain for Wudu. The prayer hall is distinguished by the existence of six mihrabs built during different periods. Five of them are flat, and the main mihrab is concave. The mosque is known for its stone minaret and is surrounded by an external staircase located near the mihrab main axis [19].

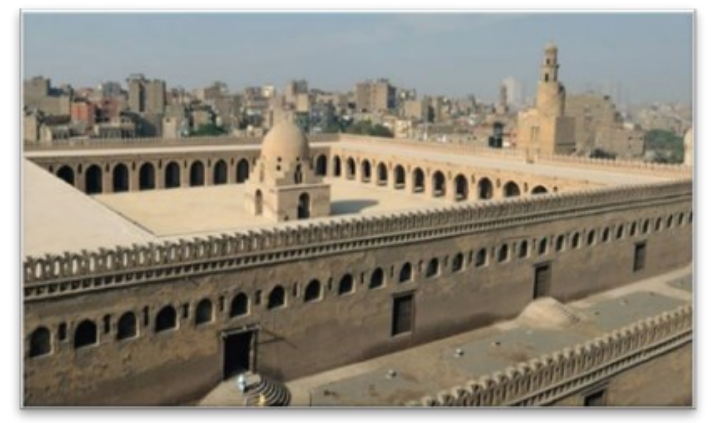

Figure 1. The Lost City of Ibn Tulun [20]

2. Iranian type and Seljuk style: Isfahan Mosque, Isfahan, Iran, 771 AD

The mosque was built in the 11th century and in the 12th century. The additions were made represented by iwans, which later became the hallmark of classical Iranian mosque architecture. This mosque is significant for being the first mosque in Iran and the Islamic world. It contains four iwans that have become the first model of its kind in architectural history in the East, as shown in Figure 2 [21]. 


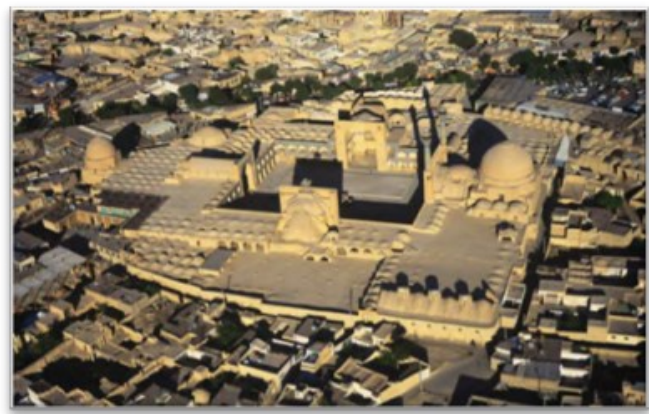

Figure 2. Isfahan Mosque [22]

3. Turkish type and Ottoman type: Süleymaniye Mosque, Istanbul, Turkey, 1557 AD

The Süleymaniye Mosque dates back to the 16th century during the reign of Sultan Suleiman. It was built within a vast complex that includes educational, health, and caravanserai buildings. This mosque was built with a plan similar to the Hagia Sophia Church, shown in Figure 3. However, the designer optimized its function as a mosque through the attempt to build the possible largest space for prayer without separating the rows of worshipers; the area of the dome was enlarged, and the building was lit through several windows on both sides of the mosque [8].

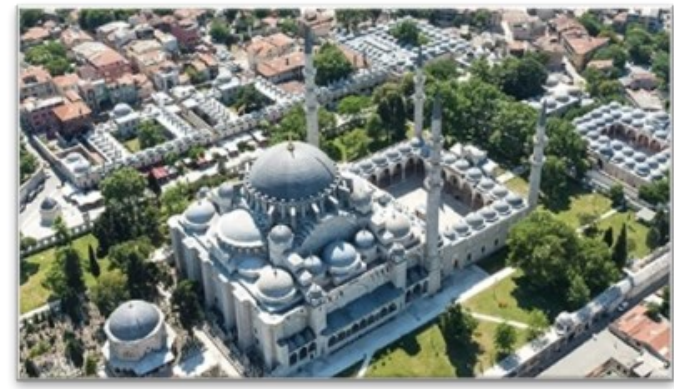

Figure 3. Süleymaniye Mosque [23]

4. Indian type: Jama Masjid, Delhi, India, 1656 AD

The mosque is located in Delhi, one of the Mughal Empire capitals in India, and it belongs to Mughal architecture. It was built in the 17th century. The mosque is located on a high platform and is ascended by several stairs at the entrance; the prayer hall is roofed with three onion domes covered by marble. The entrances to the prayer hall consist of inlaid marble panels, as shown in Figure 4 [8].

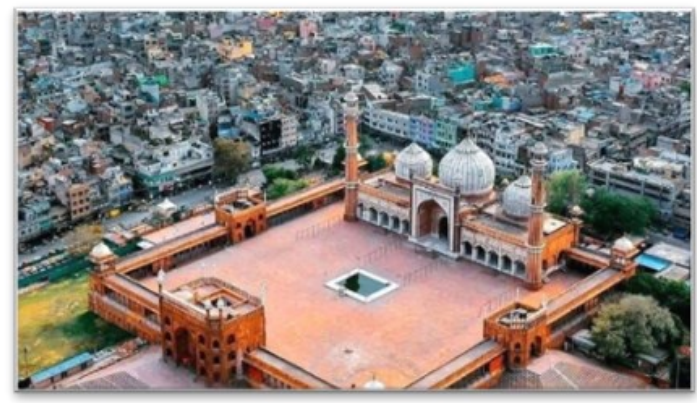

Figure 4. Jama Masjid of India [24]

\section{Chinese mosques and the mosques of Southeast} Asia: Xi'an Great Mosque, China, 742 AD

The mosque is located in Xi'an, China, and it becomes the most important mosque in the country. It was built in $742 \mathrm{AD}$, and additions were made until the 15th century. The mosque was built in Chinese architecture style and had five repeated courtyards that mimic Chinese temples, as illustrated in Figure 5. This imitation created similarities between the mosque and the earlier form of temples. Writings distinguished the interior design of the mosque from the Qur'anic verses [8].

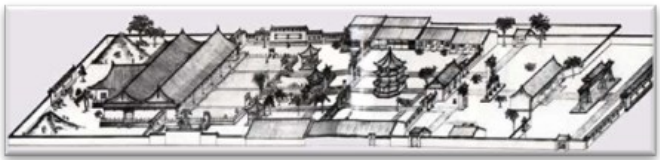

Figure 5. Drawing of Xi'an Great Mosque [25]

\section{MOSQUES FROM THE CONTEMPORARY PERIOD}

This research considered five samples belonging to five contemporary mosque trends. They were chosen because of the richness of the repetitive elements and the availability of complete information about them in terms of plans and images in recent studies.

1. Mosques that combine ancient form with contemporary style and technique: Basuna Mosque, Sohag Governorate, Egypt, 2019

The mosque is located in the village of Basuna in Northern Egypt. This mosque was constructed on the site of an old mosque that had been removed. The mosque designer tried to overcome difficulties related to the location, such as noise, climate, crowded surroundings, dust, and odours. The resulting design addressed these challenges and had a solid visual value and compatibility with the context, as shown in Figure 6. The mosque architecture included the essential elements known in ancient mosques, such as the dome and the minaret. However, the design was executed differently by using modern technology in the implementation of the building. New methods were also used to address issues related to the climate, such as ventilation and lighting. This mosque features distinct elements in the prayer hall's interior design from the mihrab and other elements [26]. The mosque was heavily influenced by ancient design, but innovative elements and modern implementation methods were used.

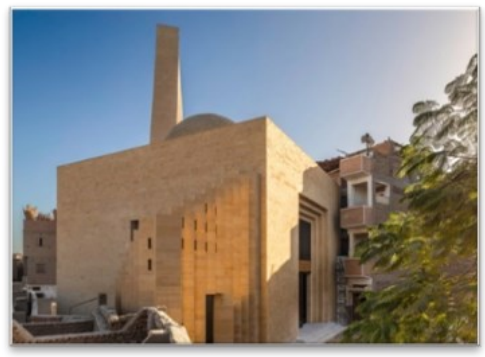

Figure 6. Basuna Mosque [26] 
2. Mosques influenced by principles of sustainability: Al-Irsyad Mosque, Central Java, Indonesia, 2010

The construction of the mosque took approximately a year. The mosque's building area is $1,100 \mathrm{~m} 2$ and has a capacity of 1,500 worshipers. The mosque has a cubic shape inspired by the shape of the Kaaba, as shown in Figure 7. Its surrounding landscape formed circular lines inspired by the Tawaf concept (pilgrims' journey around the Kaaba). The building walls were carved with $3 \mathrm{D}$ inscriptions, and these decorations formed the building openings playing an essential role in introducing lighting and natural ventilation into the mosque [27]. In addition, the mosque was designed based on sustainability trends in architecture.

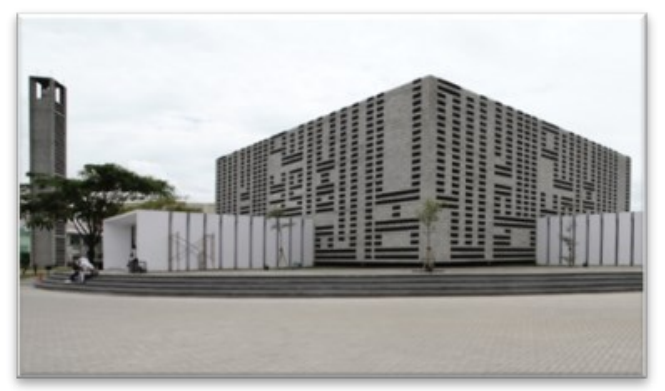

Figure 7. Al-Irsyad Mosque [28]

3. Mosques influenced by modern technology and advanced building materials: Arcapita Mosque, Manama, Bahrain, 2010

Arcapita Mosque was constructed on the same site as the Arcapita Bank building and had a capacity of 130 worshipers [29]. It consists of a cubic block of two floors, and the upper floor is for women, as shown in Figure 8 . The facades consist of triangular units and have openings to let natural light in [30].

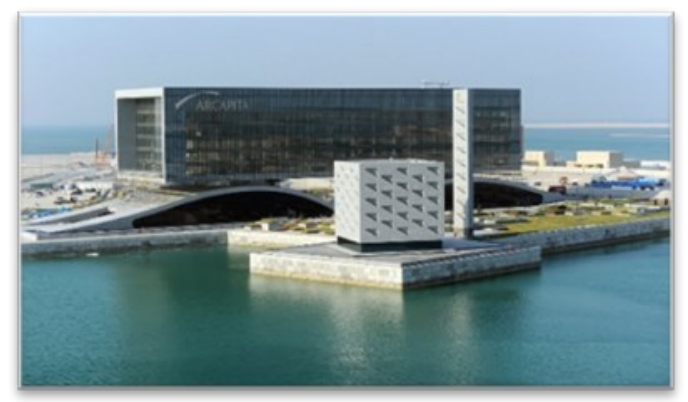

Figure 8. Arcapita Mosque [29]

4. Mosques influenced by the natural environment of the urban site: Sancaklar Mosque, Istanbul, Turkey, 2014

The mosque is located in one of the suburbs in Istanbul in Turkey. Its construction was completed in 2013. Its complete deviation distinguishes the mosque's architecture from any element or relationship with historical mosques. The mosque's shape overlaps with the natural hills that surround it from three sides. Some parts of the mosque, such as the Qibla wall, become invisible due to the hills.
Repetition of walls is used to indicate the direction of the hidden wall of the Qibla. The overlap between nature and the building create a cave atmosphere and spiritual feeling, as shown in Figure 9.

Furthermore, natural stone is used as building materials creating additional harmony with the location. The minaret has great importance in distinguishing the mosque because it is located lower than the street. Therefore, the minaret becomes the point of attraction of the mosque [31].

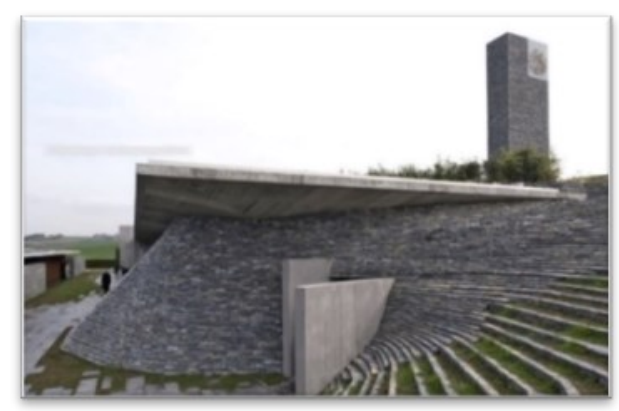

Figure 9. Sancaklar Mosque [32]

\section{Non-conventional Mosques: Imam Reza Complex Mosque, Tehran, Iran, 2012}

The basic idea of the mosque design is to encourage union and connection between different groups in society. Therefore, the designer expresses the idea of interlocking hands as evidence of unity and cohesion. The concept of interlocking hands forms the main space in the mosque, and the prayer hall is built underneath. Such main space design represents a symbolic dome shape, thus evokes the feeling of being close to God, as shown in Figure 10. Additionally, lower blocks on the sides of the building served the rest of the mosque's functions [33].

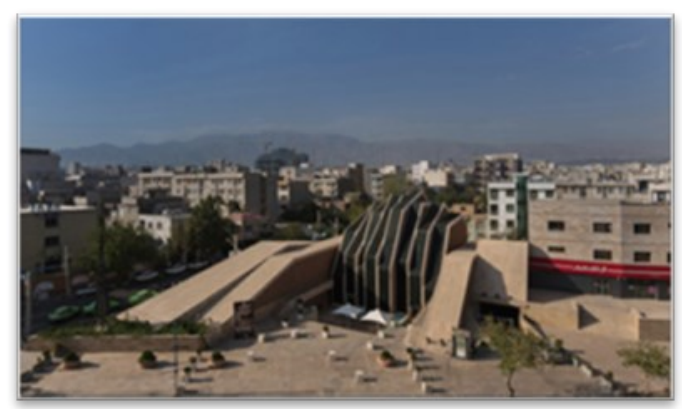

Figure 10. Imam Reza Complex Mosque [33]

\section{MEASUREMENT METHODS}

This work used a qualitative measure developed by researchers to standardize the information related to the repeated elements and the objectives of repetition that have been achieved.

1. Calculating the repetition count (RCe) for one element repetition of all samples in one period (ancient or contemporary) as in equation 1:

$$
R C e_{t p r(j)}=\sum_{k=1}^{n} e_{t p r(j)}
$$


Where

$$
\begin{aligned}
& \mathrm{RC}=\text { Repetition count } \\
& \mathrm{e}=\text { Repeated element } \\
& \mathrm{t}=\text { Element Type } \\
& \mathrm{k}=\text { The tested samples }(1-5) \\
& \mathrm{n}=\text { Total number of samples }(5) \\
& \qquad \operatorname{pr}(\mathrm{j})=\begin{array}{l}
j=1, \text { ancient period } \\
j=2, \text { contemporary period }
\end{array}
\end{aligned}
$$

2. Calculating the repetition count (RCE) of all elements repetition of all samples in one period (ancient or contemporary) as in equation 2:

$$
\mathrm{RC} E_{p r(j)}=\sum_{k=1}^{\mathrm{n}} R C e_{\mathrm{t} p \mathrm{p}(\mathrm{j})}
$$

Where

$$
\begin{aligned}
& \mathrm{RC}=\text { Repetition count } \\
& \mathrm{E}=\text { The whole set of elements } \\
& \mathrm{k}=\text { The tested samples }(1-5) \\
& \mathrm{n}=\text { Total number of samples }(5) \\
& \qquad \begin{array}{l}
j=1, \text { ancient period } \\
j=2, \text { contemporary period }
\end{array}
\end{aligned}
$$

3. Calculating the repetition ratio ( $R R e$ ) of one element repetition of all samples in one period (ancient or contemporary) as in equation 3 :

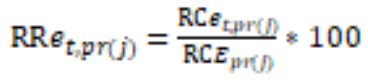

Where

$$
\begin{aligned}
& \mathrm{RR}=\text { Repetition ratio } \\
& \mathrm{e}=\text { Repeated element } \\
& \mathrm{t}=\text { Element Type } \\
& \qquad \begin{array}{l}
j=1, \text { ancient period } \\
j=2, \text { contemporary period }
\end{array}
\end{aligned}
$$

4. Calculating the repetition count (RCe) for one element repetition of all samples in both periods (ancient and contemporary) as in equation 4:

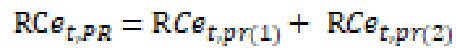

Where

$$
\begin{aligned}
& \mathrm{RC}=\text { Repetition count } \\
& \mathrm{e}=\text { Repeated element } \\
& \mathrm{t}=\text { Element Type } \\
& \mathrm{PR}=\text { Two periods (ancient and } \\
& \text { contemporary) }
\end{aligned}
$$

5. Calculating the repetition count (RCE) for all elements repetition of all samples in both periods (ancient and contemporary) as in equation 5:

$$
\mathrm{RC} E_{p R}=\mathrm{RC} E_{p r[1]}+\mathrm{RC} E_{p r(2)}
$$

Where

\section{$\mathrm{RC}=$ Repetition count}

$E=$ The whole set of elements

$\mathrm{PR}=$ Two periods (ancient and
contemporary)

6. Calculating the repetition ratio (RRe) for one element repetition of all samples in both periods (ancient and contemporary) as in equation 6:

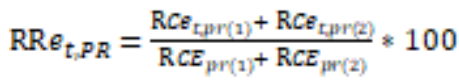

Where

$$
\begin{aligned}
& \mathrm{RR}=\text { Repetition ratio } \\
& \mathrm{e}=\text { Repeated element } \\
& \mathrm{t}=\text { Element Type } \\
& \mathrm{PR}=\text { Two periods (ancient and } \\
& \text { contemporary) }
\end{aligned}
$$

7. Calculating the appearance ratio (ARe) for one element repetition of all samples in one period (ancient or contemporary) as in equation 7:

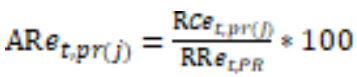

Where

$$
\begin{aligned}
& \mathrm{AR}=\text { Appearance ratio } \\
& \mathrm{e}=\text { Repeated element } \\
& \mathrm{t}=\text { Element Type scdc } \\
& \qquad \begin{array}{l}
j=1, \text { ancient period } \\
j=2, \text { contemporary period }
\end{array}
\end{aligned}
$$

\section{ANALYSIS AND RESULTS}

This section will discuss the data analysis related to the repeating elements in the two periods, as shown in Tables 1. and 2. The columns indicate the repeated elements, whereas the rows indicate the mosques representing the ancient and contemporary periods. The intersection of each element's type with a mosque is set to 1 or 0 . For example, in Table 1 . the domes field in Ibn Tulun mosque is set to 1 ; hence, repetition of domes is used in this mosque. By contrast, the minarets field is 0 , which means repetition in minarets is not applied in this mosque. The last column of other elements represents the total number of distinctive elements discovered within each sample.

The last three lines of the table represent Repetition Count for each element (RCe), the Repetition Count for all elements (RCE), and the Repetition Ratio for each element (RRe). The RCe represents the total repetition instances in a single element in all mosques, as in equation 1 . In contrast, RCE represents the total repetition instances in all elements out of all mosques as in equation 2. Finally, RRe represents each repeated element's percentage by dividing the RCe by the RCE as equation 3 . 
Table 1. Repetition of Elements in Ancient Mosques

\begin{tabular}{|c|c|c|c|c|c|c|c|c|c|c|c|c|c|c|c|}
\hline Samples & Domes & Minar ets & Arches & Ornaments & $\begin{array}{l}\text { Columns } \\
\text { \& pillars }\end{array}$ & Iwans & Openings & Bridges & Arcades & $\begin{array}{l}\text { Naves } \\
\& \text { bays }\end{array}$ & \begin{tabular}{|c|}
$\begin{array}{c}\text { Entrances } \\
\text { \& gates }\end{array}$ \\
\end{tabular} & \begin{tabular}{|l|} 
Lighting \\
elements
\end{tabular} & Pendentives & Muqarnas & $\begin{array}{c}\text { Other } \\
\text { elements }\end{array}$ \\
\hline Ibn Tulun Mosque & 1 & 0 & 1 & 1 & 1 & 0 & 1 & 0 & 1 & 1 & 1 & 1 & 0 & 1 & 2 \\
\hline Isfahan Mosque & 1 & 1 & 1 & 1 & 1 & 1 & 1 & 0 & 0 & 0 & 1 & 0 & 1 & 1 & 0 \\
\hline Süleymaniye Mosque & 1 & 1 & 1 & 1 & 1 & 0 & 1 & 0 & 1 & 0 & 1 & 1 & 1 & 1 & 0 \\
\hline Jama Mosque & 1 & 1 & 1 & 1 & 1 & 0 & 1 & 0 & 1 & 1 & 1 & 1 & 0 & 0 & 0 \\
\hline Xi'an Great Mosque & 0 & 1 & 0 & 1 & 1 & 0 & 1 & 1 & 0 & 0 & 1 & 0 & 0 & 0 & 3 \\
\hline Repetition Count of Each Element & 4 & 4 & 4 & 5 & 5 & 1 & 5 & 1 & 3 & 2 & 5 & 3 & 2 & 3 & 5 \\
\hline Repetition Count of All Elements & & & & & & & & 52 & & & & & & & \\
\hline Repetition Ratio of Each Element & \begin{tabular}{|l|l|}
$7.69 \%$ \\
\end{tabular} & $7.69 \%$ & $7.69 \mathrm{X}$ & $9.62 \%$ & $9.62 \%$ & \begin{tabular}{|l}
1.928 \\
\end{tabular} & $9.62 \%$ & $1.92 \%$ & $5.77 \%$ & $3.85 x$ & $9.62 \%$ & $5.77 \%$ & $3.85 \%$ & $5.77 \%$ & $9.62 \%$ \\
\hline
\end{tabular}

Table 2. Repetition of Elements in Contemporary Mosques

\begin{tabular}{|c|c|c|c|c|c|c|c|c|c|c|c|c|c|c|c|}
\hline Samples & Domes & Minarets & Arches & Ornaments & \begin{tabular}{|l|} 
Columns \\
\& pillars \\
\end{tabular} & Iwans & Openings & Bridges & Arcades & $\begin{array}{l}\text { Naves } \\
\text { \& bays }\end{array}$ & \begin{tabular}{|c|} 
Entrances \\
\& gates \\
\end{tabular} & \begin{tabular}{|l|} 
Lighting \\
elements
\end{tabular} & Pendentives & Muqarnas & \begin{tabular}{|c|}
$\begin{array}{c}\text { Other } \\
\text { elements }\end{array}$ \\
\end{tabular} \\
\hline Basuna Mosque & 1 & 0 & 1 & 0 & 1 & 0 & 1 & 0 & 0 & 0 & 1 & 1 & 1 & 0 & 3 \\
\hline Al-Irsyad Mosque & 0 & 0 & 0 & 1 & 1 & 0 & 1 & 1 & 0 & 0 & 1 & 1 & 0 & 0 & 3 \\
\hline Arcapita Mosque & 0 & 0 & 0 & 1 & 0 & 0 & 0 & 0 & 0 & 0 & 1 & 0 & 0 & 0 & 2 \\
\hline Sancaklar Mosque & 0 & 0 & 0 & 0 & 0 & 0 & 1 & 0 & 0 & 0 & 1 & 1 & 0 & 0 & 3 \\
\hline Imam RezaComplexMosque & 0 & 0 & 0 & 1 & 0 & 0 & 1 & 0 & 0 & 0 & 1 & 1 & 0 & 0 & 3 \\
\hline Repetition Count of Each Element & 1 & 0 & 1 & 3 & 2 & 0 & 4 & 1 & 0 & 0 & 5 & 4 & 1 & 0 & 14 \\
\hline Repetition Count of All Elements & & & & & & & & 3 & 6 & & & & & & \\
\hline Repetition Ratio of Each Element & $2.78 \%$ & $0.00 \%$ & $2.78 \%$ & $8.33 \%$ & $5.56 \%$ & $0.00 \%$ & $11.11 \%$ & $2.78 \%$ & $0.00 \%$ & $0.00 \%$ & $13.89 \%$ & 11.111 & $2.78 \%$ & $0.00 \%$ & $38.89 \%$ \\
\hline
\end{tabular}

Table 1 and Table 2 show a clear difference in the total number of repeated elements between the two periods. The total number of repeated elements in the samples taken from both periods reached 88 However, the total of repeated elements in ancient period is 52 or $59 \%$, whereas that of the contemporary period is 36 , or $41 \%$. Therefore, the repetition and the number of repeated elements generally decrease in contemporary mosques, as shown in Table 3.

Table 3. Number of Repetitions between Two Periods

\begin{tabular}{lcc}
\hline \multicolumn{1}{c}{ Period } & Repetition Count & Ratio \\
\hline Ancient & 52 & $59 \%$ \\
\hline Contemporary & 36 & $41 \%$ \\
\hline
\end{tabular}

Figure 11 shows the frequency of repeated elements for each period. Each of these elements has a different ratio of appearance in each period. Table 4 shows the difference in Appearance Ratio for each element (ARe) in both periods. Appearance Ratio is calculated by dividing the RCe for a particular period by the RCe for both periods combined as in equation 7 .

Table 4 shows a difference in the employment of each element. Some cases indicate an increase in usage, whereas others show a decrease. The following section will discuss each of these elements regarding the number of repetitions, employment rate, and appearance ratio in both periods.

1. Domes: The use of domes in the ancient period appears in four out of five mosques at a ratio of $80 \%$. By contrast, domes appear in only one out of five mosques in the contemporary period at a ratio of $20 \%$. Thus, the use of domes decreases significantly in the contemporary period.

2. Minarets: Minarets are typical in ancient mosques, and they are repeated in four out of five ancient mosques. However, minarets are not repeated in any of the contemporary mosques. Minarets appeared in some modern mosques, but they are used singularly [26]. The use of minarets may have been reduced primarily due to technical advancements; loudspeakers have reduced the importance of multiple minarets in transmitting sound in all directions[15].

3. Arches: In the ancient period, arches were employed at a ratio of $80 \%$. The repetition of arches represents this high ratio in four out of the five ancient mosques. In contrast, only one mosque in the contemporary period uses repeated arches, which represents a ratio of $20 \%$.

4. Ornamental elements: They are among the elements employed in the two periods at varying ratios. These elements were more noticeable within the ancient period in which they are repeated in all samples at a ratio of $62.5 \%$. However, in the contemporary period, ornamental elements are repeated in three samples at a rate of $37.5 \%$. This result indicates a decrease in the use of decoration in contemporary mosques.

5. Columns, pillars, and bridges: They are among the elements whose employment rates varied in the two periods. These elements are used at a high rate of $71 \%$ in the ancient period, as they appeared in all samples from this period. By contrast, these elements appear in only two samples in the contemporary period at a rate of $29 \%$. The decrease may be possible due to the emergence of modern.The development of structures leads to the decreasing need for traditional structures. Nonetheless, structural elements such as bridges are employed in contemporary mosques equal to the ancient period, indicating its continuity and importance.

6. Arcades, naves and bays, iwans, and muqarnas: Some of these structural elements used in old mosques, such as naves and bays, disappear and 


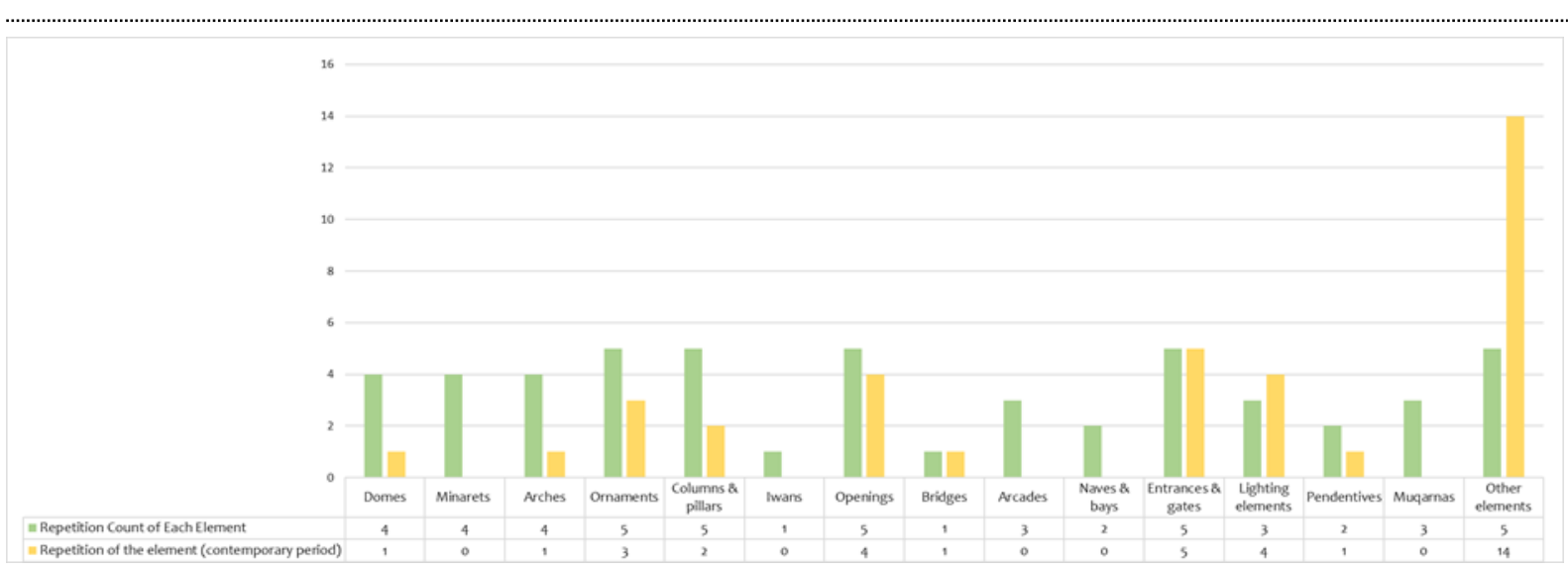

Figure 11. Repetition of Elements between the Ancient and Contemporary Periods

Table 4. Appearance Ratio of Element Repetition in Mosques

\begin{tabular}{|c|c|c|c|c|c|c|c|c|c|c|c|c|c|c|c|}
\hline Samples & Domes & Minarets & Arches & Ornaments & \begin{tabular}{|l|} 
Columns \\
\& pillars \\
\end{tabular} & Iwans & Openings & Bridges & Arcades & $\begin{array}{l}\text { Naves } \\
\text { \& bays }\end{array}$ & \begin{tabular}{|c|} 
Entr ances \\
\& gates \\
\end{tabular} & \begin{tabular}{|l|} 
Lighting \\
elements
\end{tabular} & Pendentives & Muqarnas & \begin{tabular}{|c|} 
Other \\
elements
\end{tabular} \\
\hline Basuna Mosque & 1 & 0 & 1 & 0 & 1 & 0 & 1 & 0 & 0 & 0 & 1 & 1 & 1 & 0 & 3 \\
\hline Al-Irsyad Mosque & 0 & 0 & 0 & 1 & 1 & 0 & 1 & 1 & 0 & 0 & 1 & 1 & 0 & 0 & 3 \\
\hline Arcapita Mosque & 0 & 0 & 0 & 1 & 0 & 0 & 0 & 0 & 0 & 0 & 1 & 0 & 0 & 0 & 2 \\
\hline Sancaklar Mosque & 0 & 0 & 0 & 0 & 0 & 0 & 1 & 0 & 0 & 0 & 1 & 1 & 0 & 0 & 3 \\
\hline Imam RezaComplexMosque & 0 & 0 & 0 & 1 & 0 & 0 & 1 & 0 & 0 & 0 & 1 & 1 & 0 & 0 & 3 \\
\hline & & & & & & & & & & & & & & & \\
\hline $\begin{array}{l}\text { Repetition Count of Each Element } \\
\text { Repetition Count of All Elements }\end{array}$ & 1 & 0 & 1 & 3 & 2 & 0 & 4 & 1 & 0 & 0 & 5 & 4 & 1 & 0 & 14 \\
\hline Repetition Ratio of Each Element & $2.78 \%$ & $0.00 \%$ & \begin{tabular}{|l|}
$2.78 \%$ \\
\end{tabular} & $8.33 \%$ & $5.56 \%$ & $0.00 \%$ & \begin{tabular}{|l}
$11.11 \%$ \\
\end{tabular} & $2.78 \%$ & $0.00 \%$ & $0.00 \%$ & $13.89 \%$ & $11.11 \%$ & $2.78 \%$ & $0.00 \%$ & $38.89 \%$ \\
\hline
\end{tabular}

are no longer used in contemporary mosques. Iwans, known in ancient mosques, especially Iranian and Indian mosques, are absent too. Although arcades are dominant in ancient mosques' design, they no longer appear in modern designs. Moreover, the element of muqarnas used for structural and decorative purposes in the ancient period disappear in contemporary mosques. The disappearance of these elements might attribute to technological advances in construction techniques and evolving design ideas [31].

7. Pendentives: A pendentive is a curved triangle of vaulting formed by a dome's intersection with supporting arches. It is linked to other elements, such as domes in the ancient period. The absence of domes in the contemporary period leads to the absence of pendentives. The decrease dropped to $33 \%$ in contemporary mosques from $67 \%$ in ancient mosques.

8. Entrances, gates, openings, and lighting elements: These elements are distinguished by their appearance in both periods and close shares $~ 50 \%$ \pm . This result indicates the adoption of the repetition of these elements due to continual function and design needs.

9. Other elements: Elements such as mihrabs, balconies, prayer halls, courtyards, and multifunction halls contributes $26 \%$ repetition in ancient mosques. The examples include the repetition of mihrabs and distinct decorative elements known as Shirafat (balconies) in Arabic mosques. A diversity of prayer halls can be found in Iranian mosques. In Chinese mosques, many courtyards and covered spaces roofed with gables served many purposes[11]. However, none of these elements appeared in contemporary mosques.

A set of new elements emerge in contemporary mosques. They vary significantly, too. In each mosque, a foundation of different elements appears in response to a specific effect related to the site's natural environment, climate, building materials, and other factors. These elements vary between functional and ornamental use, and the ratio of these elements reaches the highest percentage of $74 \%$. The classification of new elements is divided into external and internal elements of functional and decorative use. External elements include the repetition of units forming the facade, solid and hollow building blocks in the facade's formation, or the repetition of units that form the entrance to highlight the surrounding. Moreover, the repetition of walls and blocks is used to highlight the direction of the Qiblah. Interior elements are also used in secondary ceilings, floors, mihrabs, and other locations. 
Table 5. Objectives of Repetition in Ancient Mosques

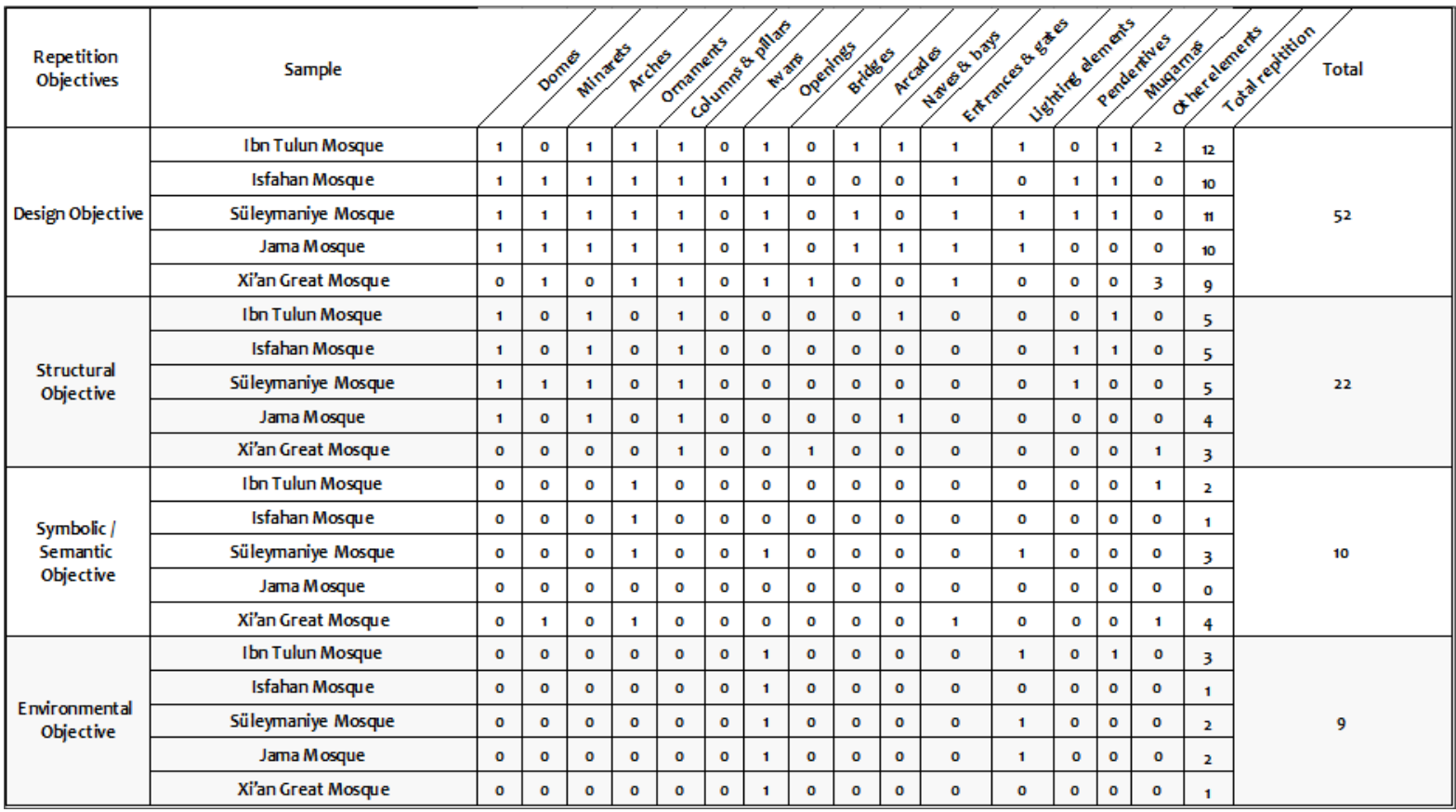

Table 5. Objectives of Repetition in Ancient Mosques

\begin{tabular}{|c|c|c|c|c|c|c|c|c|c|c|c|c|c|c|c|c|c|c|}
\hline $\begin{array}{l}\text { Repetition } \\
\text { Objectives }\end{array}$ & Sample & & & & & & & & & & & & & & & & & \\
\hline \multirow{5}{*}{ Design Objective } & Basuna Mosque & 1 & o & 1 & 0 & 1 & 0 & 1 & 0 & o & 0 & 1 & 1 & 1 & 0 & 3 & 10 & \multirow{5}{*}{36} \\
\hline & AHrsyad Mosque & 0 & 0 & $\circ$ & 1 & 1 & 0 & 1 & 1 & o & 0 & 1 & 1 & 0 & 0 & 3 & 9 & \\
\hline & Arcapita Mosque & $\circ$ & 0 & $\circ$ & 1 & 0 & 0 & 0 & 0 & o & 0 & 1 & 0 & 0 & $\circ$ & 2 & 4 & \\
\hline & Sancaklar Mosque & 0 & 0 & 0 & 0 & 0 & 0 & 1 & 0 & 0 & 0 & 1 & 1 & 0 & 0 & 3 & 6 & \\
\hline & Imam Reza Complex Mosque & 0 & 0 & 0 & 1 & 0 & 0 & 1 & 0 & 0 & 0 & 1 & 1 & 0 & 0 & 3 & 7 & \\
\hline \multirow{5}{*}{$\begin{array}{l}\text { Environmental } \\
\text { Objective }\end{array}$} & Basuna Mosque & 0 & 0 & $\circ$ & 0 & o & 0 & 1 & 0 & 0 & 0 & 0 & 1 & 1 & 0 & 0 & 3 & \multirow{5}{*}{12} \\
\hline & Altrsyad Mosque & 0 & 0 & 0 & 0 & 0 & 0 & 1 & 0 & 0 & 0 & 0 & 1 & 0 & 0 & 1 & 3 & \\
\hline & Arcapita Mosque & 0 & $\circ$ & $\circ$ & $\circ$ & $\circ$ & 0 & $\circ$ & $\circ$ & o & 0 & $\circ$ & $\circ$ & $\circ$ & $\circ$ & 1 & 1 & \\
\hline & Sancaklar Mosque & $\circ$ & $\circ$ & $\circ$ & 0 & 0 & 0 & 1 & $\circ$ & 0 & $\circ$ & $\circ$ & 1 & $\circ$ & 0 & 0 & 2 & \\
\hline & Imam Reza Complex Mosque & $\circ$ & $\circ$ & $\circ$ & 0 & $\circ$ & $\circ$ & 1 & $\circ$ & o & 0 & 0 & 1 & 0 & 0 & 1 & 3 & \\
\hline \multirow{5}{*}{$\begin{array}{c}\text { Structural } \\
\text { Objective }\end{array}$} & Basuna Mosque & 1 & o & 1 & 0 & 1 & 0 & 1 & 0 & o & 0 & 0 & $\circ$ & 1 & 0 & 1 & 6 & \multirow{5}{*}{12} \\
\hline & Altrsyad Mosque & 0 & 0 & 0 & 0 & 1 & 0 & 0 & 1 & 0 & 0 & 0 & o & 0 & 0 & 1 & 3 & \\
\hline & Arcapita Mosque & 0 & 0 & o & 0 & 0 & 0 & 0 & 0 & o & 0 & 0 & $\circ$ & 0 & 0 & 1 & 1 & \\
\hline & Sancaklar Mosque & 0 & 0 & 0 & 0 & 0 & 0 & $\circ$ & o & 0 & 0 & 0 & o & 0 & 0 & 1 & 1 & \\
\hline & Imam Reza Complex Mosque & 0 & 0 & 0 & 0 & 0 & 0 & o & 0 & 0 & 0 & 0 & o & 0 & 0 & 1 & 1 & \\
\hline \multirow{5}{*}{$\begin{array}{c}\text { Symbolic/ } \\
\text { Semantic } \\
\text { Objective }\end{array}$} & Basuna Mosque & 0 & 0 & 0 & 0 & 1 & 0 & 1 & 0 & 0 & 0 & 0 & $\circ$ & 0 & 0 & 1 & 3 & \multirow{5}{*}{10} \\
\hline & Altrsyad Mosque & $\circ$ & $\circ$ & $\circ$ & 1 & $\circ$ & $\circ$ & 0 & o & o & 0 & 0 & $\circ$ & o & 0 & o & 1 & \\
\hline & Arcapita Mosque & $\circ$ & $\circ$ & $\circ$ & $\circ$ & $\circ$ & $\circ$ & $\circ$ & $\circ$ & $\circ$ & 0 & $\circ$ & $\circ$ & o & $\circ$ & 0 & 0 & \\
\hline & Sancaklar Mosque & $\circ$ & $\circ$ & $\circ$ & 0 & 0 & 0 & 1 & 0 & 0 & 0 & 0 & $\circ$ & 0 & 0 & 2 & 3 & \\
\hline & Imam Reza Complex Mosque & 0 & 0 & o & 1 & 0 & 0 & 0 & 0 & 0 & 0 & 0 & $\circ$ & 0 & 0 & 2 & 3 & \\
\hline
\end{tabular}

Above, it describes the element repetition in the mosques in both periods. In Table 5, the columns indicate the repeated elements, whereas the rows consist of mosques from the ancient and contemporary periods. The objectives for repetition in each period are indicated separately and combined to determine the objectives and their ratio.

In the ancient period, the design is the primary objective and is followed by the structural objective. The rest of the objectives are arranged according to their importance as shown in Table 5 . In the contemporary period, the design objective is also the priority, followed by the environmental objective.

Environmental objectives have risen in importance in the contemporary period to be at par with structural objectives due to the growing interest in sustainability [27], as shown in Table 6 . In conclusion, the design objective comes first in both periods, meaning that repetitions were used for design objectives in the most significant proportion in both 
periods, followed by the rest in varying proportions between the two periods.

We conclude from previous sections that the design objective is the most important in the two periods. In the ancient period, structural objective is in second place at $23.66 \%$, and it is the most important after the design objective. However, its importance decreases in the contemporary period to $17.14 \%$. Environmental and structural objectives are of equal importance in the contemporary period; hence, environmental objective increases. By contrast, they are the least important aspect in the ancient period at only $9.68 \%$. The symbolic/semantic objective is employed at a ratio of $10.75 \%$, which represents the third most crucial objective in the ancient period. It decreases to $14.29 \%$ in the contemporary period and become the least important among all the objectives, as shown in Table 7.

Table 7 shows the percentage of the appearance of the objectives of repetition in the two periods. We noted the appearance of the design objective at a rate of $59.09 \%$ in the ancient period, compared with $40.91 \%$.
In the contemporary period, design objective is accomplished by repeating elements that achieve unity or repeating them at a certain rhythm, which gives a sense of vitality and movement at $64.71 \%$ versus $35.29 \%$ for the structural objective. Structural objective in the ancient period is manifested in repeating columns, arches, naves, bays, and other structural systems[17] Such objective aims to develop the mosque's shape and increase its area. In the contemporary period, we notice a decrease in its importance due to the rise of modern structures contributing to the increased area for mosques. We notice an increase in environmental objective from $42.86 \%$ in the ancient mosques to $57.14 \%$ in contemporary mosques. We believe the reason for the increase in the repetition of these elements is to achieve the environmental objective.

Part of the environmental objective is to follow the architectural trends towards sustainable buildings and reduce energy consumption by using repetitive elements that achieve ventilation and natural lighting [14]. Lastly, semantic/symbolic objective appears in the same proportion in both periods, indicating its equal importance in these periods.

Table 7. Objectives of Repetition in Contemporary Mosques

\begin{tabular}{|c|c|c|c|c|}
\hline & Design & Structural & Environmental & $\begin{array}{l}\text { Symbolic/ } \\
\text { Semantic }\end{array}$ \\
\hline Repetition Count of Each Objective (Ancient Period) & 52 & 22 & 9 & 10 \\
\hline Repetition Count of All Objective (Ancient Period) & \multicolumn{4}{|c|}{93} \\
\hline Repetition Ratio of Each Objective (Ancient Period) & $55.91 \%$ & $23.66 \%$ & $9.68 \%$ & $10.75 \%$ \\
\hline Repetition Count of Each Objective (Contemporary Period) & 36 & 12 & 12 & 10 \\
\hline Repetition Count of All Objective (Contemporary Period) & \multicolumn{4}{|c|}{70} \\
\hline Repetition Ratio of Each Objective (Contemporary Period) & $51.43 \%$ & $17.14 \%$ & $17.14 \%$ & $14.29 \%$ \\
\hline Repetition Count of Each Objective (All Periods) & 88 & 34 & 21 & 20 \\
\hline Repetition Count of All Objectives (All Periods) & \multicolumn{4}{|c|}{163} \\
\hline Repetition Ratio of Each Objective (All Periods) & $53.99 \%$ & $20.86 \%$ & $12.88 \%$ & $12.27 \%$ \\
\hline Appearance Ratio of Each Objective(Ancient Period) & $59.09 \%$ & $64.71 \%$ & $42.86 \%$ & $50.00 \%$ \\
\hline Appearance Ratio of Each Objective (Contemporary Period) & $40.91 \%$ & $35.29 \%$ & $57.14 \%$ & $50.00 \%$ \\
\hline
\end{tabular}

\section{CONCLUSION AND RECOMMENDATION}

Repetition is one of the most important design principles that have been employed in mosque architecture since the emergence of the first model of mosques. The first is represented in the Prophet's Mosque, followed by other mosques up to the present time.

This work reviewed previous studies and analyzed ten mosques from two periods.

Five mosques were chosen to represent the ancient period, and another five mosques represented the contemporary period. The contemporary mosques show contemporary trends in mosque architecture according to international awards and conferences.

The statistical study showed a slight decrease in the rate of using the principle of repetition and repetitive elements in contemporary mosques compared with ancient ones. This result indicated a decrease in the cases of repetition in contemporary mosques in general. In addition, employing repetition in ancient mosques was executed using certain elements such as domes, minarets, arches, columns, and decorations.

The processes of employing repetition in the contemporary mosques were characterized into external and internal elements of functional and decorative use. Examples of external elements are the repetition of units forming the facade, solid, and hollow building blocks in the facades' formation, or the repetition of units that form the entrance to highlight the surrounding. Moreover, the repetition of the walls and blocks is used to highlight the direction of the Qiblah. Interior elements are also used in secondary ceilings, floors, mihrabs, and other locations.

Some elements from the ancient period continue to be used according to the different contemporary 
mosque architecture trends. Design is the most important objective achieved by repetition in both periods. Secondary objective varies according to the focus. Hence, the ancient mosques focus on repeating elements to achieve the structural objective, whereas contemporary mosques focus on achieving the environmental objective.

Future studies can further explore the principle of repetition by addressing other details, such as repetition and the proportions and relationships between repetitive elements in mosque architecture. The study also recommends employing the information obtained in the process of designing contemporary mosques in the future.

\section{ACKNOWLEDGMENTS}

The researchers would like to acknowledge the Architectural Engineering Department-Engineering College- the University of Mosul, which provides the platform to complete the current study recorded in the research plan of the department 2020-2021.

\section{REFERENCES}

[1] C. S. Chan, "Phenomenology of rhythm in design," Frontiers of Architectural Research, vol. 1, no. 3, pp. 253-258, 2012, doi: https:// doi.org/10.1016/j.foar.2012.06.003

[2] D. H. Al-Araji, Training in Islamic Decorative Arts (Al-Hillah as a Model), attakwin fil qonuni zukhrofiyah islamiyah alkhala namudijan, 2015.

[3] A. M. Al-Khafaji and M. Aziz, "The Mechanism of Repetition and Its Impact on Perceiving the Architectural Form," Iraqi Journal of Architecture, no. 4, pp. 344-360, 2015.

[4] R. Thapa, "Rhythm in Architecture: an Aesthetic Appeal," Journal of the Institute of Engineering, vol. 13, pp. 206-214, 2018.

[5] E. M. Mohamed, "The Relationship Between Interior Architecture and Music," Modern Applied Science, vol. 12, pp. 86-112, 2018, doi: doi:10.5539/mas.v12n10p86

[6] A. A. D. Taha and O. Q. Abdulqader, "The Order of Repetition Process In Islamic Architecture Ornaments: The Case of Mosulian Traditional Houses," International Transaction Journal of Engineering, Management, \& Applied Sciences \& Technologies, vol. 11, pp. 1-13, 2020, doi: DOI: 10.14456/ITJEMAST.2020.4

[7] H. Al-Basha, Encyclopedia of Architecture, Archeology and Islamic Arts. Beirut, Lebanon:
Oriental papers for printing, publishing and distribution, 1999.

[8] B. O'Kane, Mosques: The 100 Most Iconic Islamic Houses of Worship, New York: Assouline, 2018.

[9] H. R. Hitchcock, World Architecture. An Illustrated History. Paul Hamlyn, 1963.

[10] H. M. Al-Qahtani, The principles of Islamic architecture and its contemporary transformations, Beirut, Lebanon: Center for Arab Unity Studies, 2009.

[11] A. Ali, "Mosque Architecture in Delhi: Continuity And Change in Its Morphology," Ateet, vol. Special Issue, pp. 40-57, 2012,

[12] A. Jaleel and B. M. Sultan, "Replacing The Mosque Stereotype To Displace The Islamophobia Concept," in Mosque Architecture: Present Issues And Future Ideas, pp. 771-805, 2019

[13] M. Kamal, D. M. Helal, R. Ismail, and A Eltaweel, "Mosque Design Between Iconicity And Receptiveness," in Mosque Architecture: Present Issues And Future Ideas, pp. 343-361, 2019

[14] S. D. M. Sojak, R. N. R. Shahminan, and F. Ahmad, "Architectural Ornament On Contemporary Mosque In Malaysia," in Mosque Architecture: Present Issues And Future Ideas, pp. 597-607, 2019

[15] O. S. Asfour, "Bridging The Gap Between The Past And The Present: A Reconsideration Of Mosque Architectural Elements," Journal of Islamic Architecture, vol.4, No.2, pp. 77-85, 2016, DOI: https://doi.org/10.18860/ jia.v4i2.3559

[16] B. Ghasemzadeh, A. Fathebaghalli, and A. Tarvirdinassab, "Symbols And Signs In Islamic Architecture," Revista Europeia de Estudos Artisticos, vol. 4, No. 3, pp. 62-78, 2013, DOI https://doi.org/10.37334/eras.v4i3.86

[17] J. Shafiq, "Architectural Elements in Islamic Ornamentation: New Vision in Contemporary Islamic Art," Arts and Design Studies, vol. 21, pp. 11-21, 2014

[18] AFAMA, "AFAMA Third Cycle Short Listed Mosques," Abdullatif Al Fozan Award, Jan. 28, 2019. https://alfozanaward.org/afama-thirdcycle-short-listed-mosques/ (accessed Nov. 10, 2020). 
[19] D. Behrens-Abouseif, Islamic Architecture in Cairo an Introduction. Leiden, New York, København: Köln E.J. BRILL, 1989.

[20] N. Fletcher-Jones, "The Lost City of Ibn Tulun," Egypt Today, Feb. 02, 2016. https:// www.egypttoday.com/Article/4/3023/TheLost-City-of-Ibn-Tulun (accessed Nov. 10, 2021).

[21] UNESCO, Islamic Republic of Iran Iranian Cultural Heritage, Handierafls \& Tourism Organization ICHHTO, Masjed-e Jame' of Isfahan For Inscription on the World Heritage List, Tehran: UNESCO World Heritage Convention, 2011.

[22] A. A. R. Ahmed, Islamic architecture in Egypt from the Arab conquest until the end of the Mamluk era (21-923) (641-1517) AD. Cairo, 2009.

[23] T. Çarşısı, "If You Don't Visit the Süleymaniye Mosque, You'll Regret It Later," The Instabul Insider. https://theistanbulinsider.com/if-youdont-visit-the-suleymaniye-mosque-you-willregret-it-later/ (accessed Nov. 10, 2020).

[24] "Jama Masjid (Delhi), Delhi." https:// www.nationalheraldindia.com/india/must-see -amazing-picture-of-empty-jama-masjid-onramzans-1st-day-first-since-1857 (accessed Nov. 10, 2020)
[25] “Huajuexiang Mosque," Archnet. https:// www.archnet.org/sites/3973 (accessed Nov. 10, 2020).

[26] "Basuna Mosque." Mosqpedia. https:// mosqpedia.org/en/mosque/189 (accessed Nov. 10, 2020)

[27] A. H. Murtan and S. Sardi, "GREEN AND SUSTAINABLE STRUCTURE OF THE MOSQUE OF AL-IRSYAD SATYA INDONESIA," presented at the 2nd INTERNATIONAL CONFERENCE ON MOSQUE ARCHITECTURE (ICMA 2019), Kuala Lumpur, 2019.

[28] "AL-Irsyad Mosque, Central Java, Indonesia 1," Mosqpedia. https://mosqpedia.org/en/ mosque/74 (accessed Nov. 10, 2020)

[29] "Arcapita Mosque," Alfozanaward. https:/l alfozanaward.org/mosques/arcapita/ (accessed Nov. 10, 2020)

[30] "Arcapita Mosque (East Park Mosque)." Mosquetabi. https:// mosquetabi.blogspot.com/2019/04/arcapitamosque-east-park-mosque.html (accessed Nov. 10, 2020)

[31] B. Gür, "Sancaklar Mosque: Displacing the Familiar," International Journal of Islamic Architecture, vol. 6, pp. 165-193, 2017, doi: https://doi.org/10.1386/ijia.6.1.165_1

[32] "Sancaklar Mosque, Istanbul, Turkey." Mosqpedia, https://mosqpedia.org/en/ mosque/60 (accessed Nov. 10, 2020)

[33] "Imam Reza Complex Mosque," Mosqpedia. https://mosqpedia.org/en/mosque/77 (accessed Nov. 10, 2020) 